\title{
Proverbs: Prose or poetry?
}

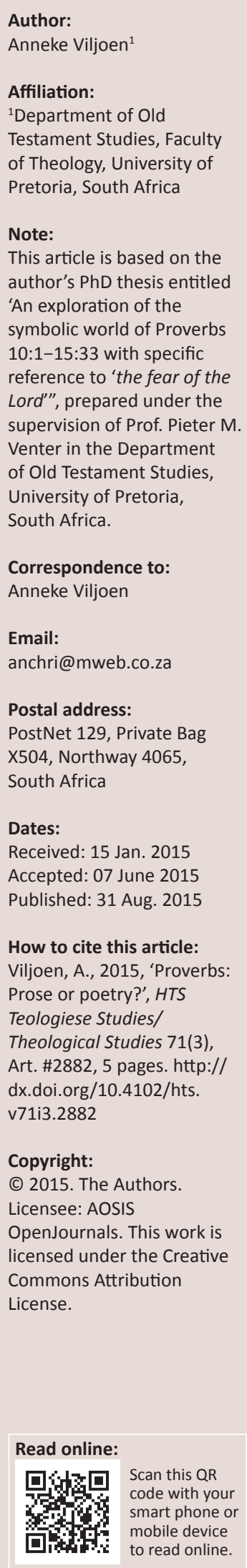

Should Proverbs be read as prose or poetry? Considering the language craft is of essential significance for a hermeneutical enquiry into the biblical book of Proverbs. Five suppositions to support the presupposition that Proverbs is best read as poetry were considered.

\section{Introduction}

On reading the biblical book of Proverbs one instinctively tends to regard the proverbs as a language craft. ${ }^{1}$ But should the book be read as prose or poetry, considering that the form of the language craft is vital in a hermeneutical inquiry into the biblical book of Proverbs? ${ }^{2}$

In his hermeneutical thoughts, Ricoeur (1977:15) cautioned against the separation of the form and content of a discourse. It became apparent to him that the form in which a message was encoded and the content that the message communicated were inextricably interwoven. McKane ([1979] 1990:167) stated that 'what is said' could not be detached from 'how it is said' since the force of any discourse arises out of a blending of form and content; separating the two would neutralise that force.

Alter (1985:4) perceives the necessity of the question as to the kind of language craft one encounters in a text for the heuristic process. He notes the importance of understanding the linguistic system used in a text in order to appreciate what kinds of meaning and representations of human and divine reality were made possible by the particular rhetorical vehicle (cf. Berlin [1985] 1992:17). Indeed, the form of a discourse can be regarded as a means by which the writer utilises the available resources of literary expression to allow a fuller understanding of the message (Alter 1985:183-184; Burden 1986:40; Potgieter 2002:1372). The author employs the dynamics of the various literary genres or modes of discourse as the 'means of production' (Ricoeur in Reese [1979] 1990:385). It is important to recognise the linguistic system of a text since the form of a text, as its encoding, becomes an important key to interpreting and appreciating the text itself (Burden 1986:40; Human 1999:357; Loader 1986:112).

\section{Parallelism as stereotypical communication pattern in biblical literature}

According to Deist (1986:23-24), a text may be described according to at least two aspects, namely how the text is organised and how the text functions. Specific situations and/or contexts require specific ways in which a message may be coded; in this way, set patterns of communication (whether oral or written) develop within a community or culture that in time become stereotyped. Identifying such stereotypical communication patterns may help the listener or reader to understand the communicated message better.

Robert Lowth identified parallelism as a stereotypical communication pattern in the biblical text and promoted it to a place of prominence in biblical studies (Lowth in Berlin [1985] 1992:1; Burden 1986:49; Gottwald [1985] 1987:522), establishing it as the major organising principle or key distinguishing characteristic of Hebrew verse (Alter 1985:204; Byargeon 2002:281; Landy 1984:62; Nel 1992:135; Petersen \& Richards 1992:2). However, the prevalence of semantic parallelism has been questioned (Alter 1985:3-4; Burden 1986:51; Petersen \& Richards 1992:1-2). Kugel questioned the equation of poetry and parallelism and raised reservations about whether one could actually

\footnotetext{
1.I prefer the term language craft to other alternatives such as language communication or discourse strategy. This is in accordance with Ricoeur's understanding (and Reese's) of the author as an 'artisan at work in discourse' (Ricoeur in Reese [1979] 1990:391). The author of a biblical text very purposefully crafts its language into a work of art that calls for the reader's response. In his book The art of Biblical poetry Alter (1985) also illustrated how the crafting of a text shapes the heuristic possibilities of the text.

2. Here I draw on and develop insights concerning the second pole (of four) of a Ricoeurian hermeneutic. For a summary of the structuring considerations of a Ricoeurian hermeneutic and to determine where the second pole fits into Ricoeur's hermeneutic approach, see
} Viljoen (2014). 
differentiate between prose and poetry in biblical literature and again brought up the question as to what the formal elements of scriptural writings were (cf. Alter 1985:4; Berlin [1985] 1992:4-7).

Alter (1985:4) disagrees with Kugel and, distinguishing between prose and poetry, chooses to read Proverbs as poetry. He states that, in purely formal terms, the poetic character of the text is nowhere more evident than in the book of Proverbs (Alter 1985:163). Landy (1984:66-68), however, sides with Kugel in stating that 'there is no absolute dividing line between poetry and prose in the Bible.' He prefers speaking of the poetic and prosaic ends of a continuum: " $[P]$ oetry" and "prose" are on a continuum whose extremes are not "high" and "low", nor "form" and "content", but two linguistic relations to reality' (Landy 1984:68). In a summary of her viewpoint, Berlin ([1985] 1992:16) concludes that '[ $p$ ]oetry uses parallelism as its constitutive or constructive device, while non-poetry, though it contains parallelism, does not structure its message on a systematic use of parallelism.' Referring specifically to the wisdom corpus, Loader (1986:107) distinguishes between poetic wisdom texts and prosaic wisdom texts.

The lack of consensus among scholars is evident. ${ }^{3}$ Most scholars nevertheless seem to agree with Davis (2009:266) in recognising that 'biblical proverbs represent language in its most condensed form.' From what follows, it should be clear that my own presupposition is that poetry is indeed discernible from prose and that Proverbs (the cited proverbs in particular) may be read as poetry.

\section{Suppositions}

My presupposition is grounded in five suppositions that became apparent to me while studying Proverbs. Considered separately neither of them is sufficient to support the presupposition, yet together they seem to persuade one to read Proverbs as poetry rather than prose. I will admit that this persuasion is rather subtle. A reader instinctively reads the proverbs as poetry and the impression of these suppositions is more subconscious than conscious. ${ }^{4}$ Alter (1985) (cf. also Petersen \& Richards 1992:2) notes that:

[A] good many of the complex effects of the poem are communicated to the reader or listener subliminally, though a conscious awareness of certain salient formal devices may help focus attentiveness. (p. 205)

\footnotetext{
3.Be as it may, insights from scholars who disagree may be used with great fruitfulness Insights from various scholars with differing opinions on what Petersen and Richards (1992:13-14) call the 'poetry-prose continuum' and what Berlin ([1985] 1992:5) terms 'the prose-poetry problem' will be used to formulate the suppositions that underlie my presupposition regarding a reading strategy of Proverbs as prose or poetry. The insights used will reflect the particular scholar's viewpoint and choice of terminology: Alter for instance speaks of poetry while Kugel (1981) refers to the continuum of low or high rhetorical style.

4.This is the main contribution of the article. By formulating the five supposition it makes conscious for readers of the book of Proving the five supposition instines conscious for readers of the book of Proverbs what instinctively or subconsciously do. To the best of my knowledge the existing scholarly research has not as of yet formulated and grouped available research into workable suppositions that support the presupposition that Proverbs is best read as poetry.
}

The five suppositions are:

1. parallelism as constructive device

2. the sign of the poetic function

3. poetry: a text convention

4. a special way of imagining the world

5. metaphoric play.

I will now consider each in turn.

\section{Parallelism as constructive device}

Firstly, one should bear in mind that the writers and/or redactors of biblical texts did not consciously label their writings 'poetry' or 'prose'. ${ }^{5}$ The dividing line between prose and poetry is not clear cut, especially if one considers that there is poetical prose (e.g. Ps 78) and prosaic poetry (e.g. Ex 2:1-7) (Burden 1986:57; Petersen \& Richards 1992:13). All imaginative prose has a poetic quality, and a great deal of poetry is prosaic (Landy 1984:78). But this does not mean that differentiation between prose and poetry does not exist (Berlin [1985] 1992:4; Burden 1986:57; Petersen \& Richards 1992:14).

Along with Landy (1984:68) and Kugel (1981), one has to admit to have doubts about an absolute dividing line between prose and poetry in the Bible; nonetheless, I agree with Alter (1985:163) that the poetic character of the text, in purely formal terms, is uniquely evident in the book of Proverbs. Berlin's ([1985] 1992:5, 16) observation that poetry uses parallelism - together with terseness - as its constitutive or constructive device, as well as Fox's view (2004:165) of parallelism being crucial to the workings of the aphorisms in Proverbs, is highly relevant in studying Proverbs.

Alter (1985:163) notes that most proverbs in Chapter 10 and subsequent chapters take up one poetic line and that the boundaries of the lines are clearly marked off by symmetries in meaning, syntax and rhythm. Proverbs 10:27 will serve as an illustration:

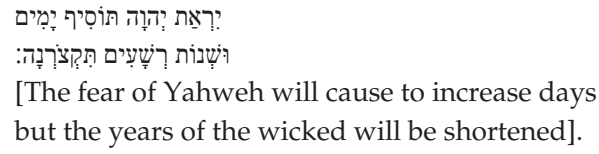

The proverb consists of parallelism contrasting the fear of the Lord with wickedness, and an increase of days with shortened years. Each colon ends with the consequences of the reader's choice. The severity of the consequence of a choice for wickedness is underlined by the contrast of the increase of days with the years being shortened. Through the structure of the proverb the consequences of the two options are contrasted with each other and spelled out clearly.

Another example from Proverbs 15:16 will illustrate this supposition. In the so-called 'better-than' (contrastive)

5.Berlin ([1985] 1992:5) noted that Kugel was even reluctant to label what we have in the biblical writings as literature as neither the writings themselves nor their writers or redactors named it so. 
proverbs of which Proverbs 15:6 is an excellent example; inversion and even subversion are created through binary opposition (Nel 2002:444):

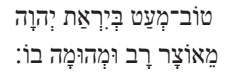

[Better a little in the fear of Yah wehthan a great storehouse and panic in it].

Proverbs 14:27 offers one more illustration:

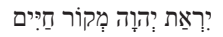

[The fear of Yahweh the source of life to keep far from the snares of death].

The proverb is structured by parallelism; simultaneously setting up a relationship of equivalence between the fear of the Lord and the purpose of avoiding the snares of death, as well as a relationship of opposition between the source of life and snares of death.

These representative examples demonstrate that parallelism is the constitutive or constructive device of the proverbs which, together with their terseness, is crucial to the workings of these aphorisms.

\section{The sign of the poetic function}

Secondly, parallelism in prose, as in poetry, is the sign of the poetic function (Berlin [1985] 1992:9; Landy 1984:78). ${ }^{6}$ The poetic function concerns both poetry and prose and therefore, as Landy (1984:78) points out, it is not an objection to a theory that it applies to both these language crafts. In biblical poetry, parallelism combines with terseness to mark poetic expression in the Bible (Berlin [1985] 1992:5).

By employing the linguistic phenomenon of parallelism, the reader's attention is focused on the message of the text for its own sake. ${ }^{7}$

\section{Clifford (2009) notes that:}

[The] two lines of Hebrew rhetoric, synthetic or antithetic, extend the thought and add drama. They invite the reader to read both lines and take the additional step of relating one line to the other. (p. 247)

It is this focus on the message as such, by the use of parallelism, which is the sign of the poetic function in combination with terseness that marks Proverbs as poetry.

Proverbs 14:26 is a good example:

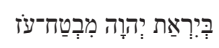

6.The poetic function is the set (Einstellung) towards the message as such, focus on the message for its own sake' (Jacobson in Berlin [1985] 1992:9; also Ricoeur 1976:36).

7.This principle is worded from a different angle by Burke (1969:50). For him, 'the notion of persuasion to attitude would permit the application of rhetorical terms to purely poetic structures; the study of lyrical devices might be classed under the head of rhetoric, when these devices are considered for their power to induce or communicate states of mind to readers.'
[In the fear of Yahweh the trust of strength and for his sons he will be a place of refuge].

The second colon is a continuation and completion of the thought in the first and carries it forward. Both halves of the proverb focus on the message that the aphorism wants to convey by making use of (progressive or climactic) parallelism: Yahweh is a safe assurance for those who fear the Lord.

\section{Poetry: A text convention}

Thirdly, and related to the second supposition, poetry is a text convention according to which poets organise their texts (Burden 1986:68). Alter (1985:167) states that as an expression of mainline wisdom activity, the book of Proverbs enhances the presupposition that wisdom is a language craft. It is neither merely the versification of traditional wisdom, a formal means for impressing a message on mind and memory (Alter 1985:163), nor a 'translation' into parallel versets of moral precepts (Alter 1985:183). The authors of poetic texts draw on the resources of poetic expression to achieve a better grasp of their subject (Alter 1985:183), and this is strikingly evident in Proverbs.

The smoothness of the parallelistic lines is, according to Alter (1985:164), not at all surprising. The proverbs are devised to transmit the wisdom of the sages by their unperturbed flow in language, the wisdom that 'derives from a sense of balanced order, confident distinction, assured consequence for specific acts and moral stances.' The ingenious construction of Proverbs 14:2 confirms Alter's observation:

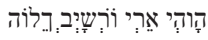

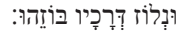

[Walker in his straightness fearer of Yahweh but goer on his wrong ways despiser of him].

Landy (1984:78) notices that parallelism in prose often marks the introduction of the divine into the storyline. In this way, the author of a biblical text would use the resources of poetic expression to mark this significant occurrence in the text. Clifford (2004:157) sees a similar introduction at work in Proverbs by the use of poetic expression: The differentness or otherness of a proverb from ordinary speech 'makes it appear "given", "revealed", "always there" and so captures our respect and attention.' In this way the resources of poetic expression in Proverbs may also mark the convergence of the divine and human reality through the impression of their being revealed (revealedness) that the proverbs convey. See as an example Proverbs 15:33:

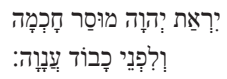

[The fear of Yahweh the instruction of wisdom and before honour humility].

The proverb seems to be simply stating a revealed truth.

From a slightly different but related view, Alter (1985:164) sees meaning arising from the complicated interaction 
between the two halves of the line that are perspicaciously joined together. This is most obvious in Fox's (2004) explanation of the rhetoric of disjointed proverbs that skilfully utilise the wording of one half of the line to say something (complementing or elaborating) about the other half (cf. Fox 2009:494-498). Proverbs 15:16 is a good example:

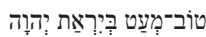

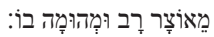

[Better a little in the fear of Yahweh than a great storehouse and panic in it].

At first sight the two halves of the proverb do not match, yet a closer reading and some pondering reveal the interaction between them.

\section{A special way of imagining the world}

My fourth supposition flows from the previous one. Alter (1985) words it aptly:

Poetry is a special way of imagining the world, or to put this in more cognitive terms, a special mode of thinking with its own momentum and its own peculiar advantages. (p. 205)

Texts with a wisdom perspective use this special way of imagining the world to reference the symbolic world that the wisdom scribes envision for their readers through the text. Figures of speech and poetic devices such as metaphor, antithetic parallelism and chiasm are used to convey the wisdom understanding of reality (cf. Loader 1986:107-110). This is especially apparent in Proverbs.

This becomes most evident when the corollary of antithetic parallelism is considered. The general observation is that antithetic parallelism dominates Proverbs 10:1-15:33 (Clements 2003:446; Perdue 2000:159; Ross 2008; Stek 2001:369; Treier 2011:61). Composing proverbs with an antithetical structure, ${ }^{8}$ and combining such a large number of them into one collection, 9 underlines the world view of the sages which is conveyed to the reader through the proverbs (Sandoval 2006:9).

The sages see humanity as divided into two parts antithetically opposed to each other: the righteous-wise versus the wickedfools. This bipolarity lies at the core of the sages' belief that is more than just a convenient and simple way of describing human society; they view it as something deeply engraved in the heart of mankind (Frydrych 2002:32). Proverbs 14:2 is an excellent example:

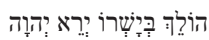

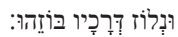

[Walker in his straightness fearer of Yahweh but goer on his wrong ways despiser of him].

In the proverb the bipolar structure of reality is revealed: The fearer of Yahweh that walks in straightness stands antithetically opposed to and is contrasted with despisers of him that goes on wrong ways.

8.The work of the authors or composers of the proverbs.

9.The work of the redactors of the collections.

\section{Metaphoric play}

Lastly, the connection between metaphoric play and poetry provides an important key to understanding Proverbs as poetry. Ricoeur (1976:46) quotes Beardsley's observation that metaphor is a poem in miniature. According to Williams ([1987] 1990:275) '[m]etaphoric play is the most important element of wisdom poetics.' The book of Proverbs employs metaphoric play to imagine or picture a symbolic reality. The crafting of the proverbs is a creative expression and brings the reader into a new relationship with that reality that is shaped through the text. A metaphor is an inherently playful and imaginative way of making sense of reality; it is effective because of the similarity as well as the dissimilarity in both vehicle and tenor (Melchert 1998:71-72). The text thus endows its readers with a considerable charge; it becomes their joy and responsibility to fill in the gaps necessarily left by the metaphors. If a metaphor is too manifest, the metaphoric play is frustrated and the metaphor itself is destroyed (Melchert 1998:71-72; cf. Ricoeur 1976:52).

Proverbs 14:27 exploits metaphoric play to achieve the second order reference that Ricoeur (1975:84; cf. 1976:56-57) understands biblical text to be referencing:

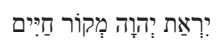

[The fear of Yahweh the source of life to keep far from the snares of death].

Dependant on as a source of life, a source (fountain) was a well-known entity in the biblical world. In what way the fear of the Lord resembles a fountain is left to the reader of the proverb to discover.

\section{Concluding remarks}

Longman (2006:33) notes that to read Proverbs profitably, one must know how to read poetry. Alter (1985) affirms that the poetic vehicle makes a vital difference in communication, so that:

$[A] \mathrm{n}$ awareness of the nuances of poetic form, seen against the general background of poetic practice and convention in the Bible, will help us grasp the liveliness, the depth of experiencewise reflection, the intellectual vigour, of these didactic texts. (p. 184)

Though there most certainly are prosaic elements in the book of Proverbs that I would not wish to deny, ${ }^{10}$ the building blocks for these are mostly poetic aphorisms. Noting how parallelism is used as a constructive device in the proverbs, the reader gains insight into the equivalences and/or oppositions their structure communicates. Parallelism is the sign of the poetic function through which the reader's attention is focused on the message of the text for its own sake. As a text convention and language craft, the sages utilise the resources of poetic expression to organise their text, thus helping the reader to achieve a fuller understanding of their subject. The proverbs use this special way of imagining 10.For example Proverbs $7: 3-23$. 
the world to reference the symbolic world that the wisdom scribes envision for their readers through the text. Lastly, the connection between metaphoric play and poetry provides an important key to understanding Proverbs as poetry.

Being conscious of the five suppositions that I proposed to support the presupposition that the wise sayings in Proverbs are best read as poetry may aid the reader to savour more of their richness, and to delight in their wisdom.

\section{Acknowledgements}

\section{Competing interests}

The author declares that she has no financial or personal relationships which may have inappropriately influenced her in writing this article.

\section{References}

Alter, R., 1985, The art of biblical poetry, Basic Books, New York, NY.

Berlin, A., [1985] 1992, The dynamics of biblical parallelism, Indiana University Press, Bloomington, IN.

Burden, J.J., 1986, 'Poëtiese tekste', in F.E. Deist \& W.S. Vorster (reds.), Woorde wat ver kom, bl. 37-68, Tafelberg-Uitgewers, Kaapstad.

Burke, K., 1969, A rhetoric of motive, University of California Press, Berkeley, CA.

Byargeon, R., 2002, 'Listening to the lyrics: Interpreting Old Testament wisdom literature and poetry', in B. Corley, S. Lemke \& G. Lovejoy (eds.), Biblical hermeneutics: A comprehensive introduction to interpreting Scripture, pp. 280300, Boardman \& Holman Publishers, Nashville, TN.

Clements, R.E., 2003, 'Proverbs', in J.D. Dunn \& J.W. Rogerson (eds.), Eerdmans commentary on the Bible, pp. 437-466, Wm. B. Eerdmans Publishing, Grand Rapids, MI

Clifford, R.J., 2004, 'Your attention please! Heeding the proverbs', Journal for the Study of the Old Testament 29(2), 155-163. http://dx.doi.org/10.1177 /030908920402900203

Clifford, R.J., 2009, 'Reading Proverbs 10-22', Interpretation: A Journal of Bible and Theology 63, 242-253, viewed 08 June 2012, from http://int.sagepub.com/ content/63/3/242

Davis, E.F., 2009, 'Surprised by wisdom: Preaching Proverbs', Interpretation: A Journal of Bible and Theology 63, 264-277, viewed 15 June 2012, from www.http://int. sagepub.com/content/63/3/264

Deist, F.E., 1986, 'Die skrywer, sy teks en sy gehoor', in F.E Deist \& W.S. Vorster (reds.), Woorde wat ver kom, bl. 16-36, Tafelberg-Uitgewers, Kaapstad.

Fox, M.V., 2004, 'The rhetoric of the disjointed proverb', Journal for the study of the Old Testament 29(2), 165-177. http://dx.doi.org/10.1177/030908920402900204

Fox, M.V., 2009, Proverbs 10-31: A new translation with introduction and commentary, Yale University Press, New Haven, CT/London.

Frydrych, T., 2002, Living under the sun: Examination of Proverbs and Coheleth, Brill, Leiden. (Supplements to Vetus Testamentum, 90).
Gottwald, N.K., [1985] 1987, The Hebrew Bible: A socio-literary introduction, Fortress Press, Philadelphia, PA.

Human, D.J., 1999, 'Die literêr-historiese lees van 'n teks', Skrif en Kerk 20(2), 354-368.

Kugel, J.L., 1981, The idea of Biblical Poetry. Parallelism and its history, Yale University Press, New Haven, CT.

Landy, F., 1984, 'Poetics and parallelism: Some comments on James Kugel's "The idea of Biblical poetry", Journal for the study of the Old Testament 28, 61-87.

Loader, J.A., 1986, 'Tekste met 'n wysheidsperspektief', in F.E. Deist \& W.S. Vorster (reds.), Woorde wat ver kom, bl. 103-122, Tafelberg-Uitgewers, Kaapstad.

Longman, T., 2006, Proverbs, Baker Academic, Grand Rapids, MI. (Baker commentary on the Old Testament Wisdom and Psalms)

McKane, W., [1979] 1990, 'Functions of language and objectives of discourse according to Proverbs 10-30', in M. Gilbert (ed.), La sagesse de l'Ancien Testament, pp. 166-185, Leuven University Press, Leuven.

Melchert, C.F., 1998, Wise teaching: Biblical wisdom and educational ministry, Continuum International Publishing Group, New York, NY.

Nel, P.J., 1992, 'Parallelism and recurrence in Biblical Hebrew poetry: A theoretical proposal', Journal of Northwest Semitic Languages XVIII, 135-143.

Nel, P.J., 2002, 'The rhetorics of Wisdom's ethics', Old Testament Essays 15(2), $435-452$.

Perdue, L.G., 2000, Proverbs, Interpretation: A Bible commentary for teaching and preaching, John Knox Press, Louisville, KY.

Petersen, D.L. \& Richards, K.H., 1992, Interpreting Hebrew poetry, Augsburg Fortress, Minneapolis, MN.

Potgieter, J.H., 2002, 'The (poetic) rhetoric of wisdom in Proverbs 3:1-12', Hervormde Teologiese Studies 58(4), 1357-1374.

Reese, J.M., [1979] 1990, 'Can Paul Ricoeur's method contribute to interpreting the book of Wisdom?', in M. Gilbert (ed.), La sagesse de l'Ancien Testament pp. 84-396, Leuven University Press, Leuven.

Ricoeur, P., 1975, 'Biblical Hermeneutics', Semeia 4, 29-148.

Ricoeur, P., 1976. Interpretation theory: Discourse and the surplus of meaning, Texas Christian University Press, Fort Worth, TX.

Ricoeur, P., 1977, 'Toward a hermeneutic of the idea of Revelation', Harvard Theological Review 70, 1-37.

Ross, A.P., 2008, 'Proverbs', in L. Tremper \& D.E. Garland (eds.), Proverbs - Isaiah: The expositor's Bible commentary, Grand Rapids, Zondervan, viewed 16 June 2012, from http://www. http://Obooks.google.co.za.innopac.up.ac.za/books?h $=e n \& \mid r=\& i d=j 7 x c b W g r D x s C \& o i=f n d \& p g=P A 11 \& d q=$ proverbs+commentary\&ots $=0 G u L d l f s A b \& s i g=z 0$ gkmAjXTFxo5xFPmFhRbsPJJgE\#v=onepage \&q=proverbs $\% 20$ commentary\&f=false

Sandoval, T.J., 2006, The discourse of wealth and poverty in the book of Proverbs, Brill, Leiden.

Stek, J.H., 2001, 'Proverbs: An introduction', Calvin Theological Journal 36, 365-371.

Treier, D.J., 2011, Proverbs and Ecclesiastes, Brazos Press, Grand Rapids, MI. (Brazos Theological commentary on the Bible).

Viljoen, A., 2013, 'An exploration of the symbolic world of Proverbs 10:1-15:33 with specific reference to "the fear of the Lord"', PhD thesis, Dept. of Old Testament Studies, University of Pretoria.

Viljoen, A., 2014, 'The structuring considerations of a Ricoeurian hermeneutic employed in a reading of Proverbs 14:2', HTS Teologiese Studies/Theological Studies 71(3), 7. http://dx.doi.org/10.4102/hts.v71i3.2849

Williams, J.G., [1987] 1990, 'Proverbs and Ecclesiastes', in R. Alter \& F. Kermode (eds.), The literary guide to the Bible, pp. 263-282, Harvard University Press, Cambridge. 